\title{
HISTOPATHOLOGICAL PATTERNS OF SURFACE EPITHELIAL TUMOURS OF OVARY WITH OESTROGEN AND PROGESTERONE RECEPTOR EXPRESSION
}

\author{
Arun B. Harke1, Ramamurthy Madhumittha², Sekar Manjani³, Thukkaram Chitra ${ }^{4}$, Ekambaranathan Saravanan ${ }^{5}$, Sigamani Karthik6, \\ Balakrishnan Shobana ${ }^{7}$
}

1 Professor, Department of Pathology, Karpaga Vinayaga Institute of Medical Sciences and Research Centre, Maduranthakam. 2Final Year Postgraduate Student, Department of Pathology, Karpaga Vinayaga Institute of Medical Sciences and Research Centre. ${ }^{3}$ Final Year Postgraduate Student, Department of Pathology, Karpaga Vinayaga Institute of Medical Sciences ad Research Centre. ${ }^{4}$ Professor and HOD, Department of Pathology, Karpaga Vinayaga Institute of Medical Sciences and Research Centre. ${ }_{5}^{5}$ Associate Professor, Department of Pathology, Karpaga Vinayaga Institute of Medical Sciences and Research Centre. ${ }^{6}$ Assistant Professor, Department of Pathology, Karpaga Vinayaga Institute of Medical Sciences and Research Centre. ${ }^{7}$ Assistant Professor, Department of Pathology, Karpaga Vinayaga Institute of Medical Sciences and Research Centre.

\section{ABSTRACT}

\section{BACKGROUND}

In the female genital tract, ovarian tumours are the most common neoplasms amongst which the surface epithelial tumours predominate.

\section{AIM}

To characterise ovarian tumours based on gross and histopathological findings. To study the incidence of ovarian neoplasms and age-related occurrence of the same. To carry out ER and PR status of surface epithelial tumours wherever possible.

\section{MATERIALS AND METHODS}

A detailed retrospective and prospective study of 70 ovarian neoplasms was done from August 2012 to July 2015 taking into account the relevant clinical data. All the cases of cystectomy, oophorectomy, and total abdominal hysterectomy with bilateral or unilateral salpingo-oophorectomy were included in the present study. Exclusion criteria set during the present study was to exclude all those patients having abdominal masses due to causes other than ovarian tumours. The correlation of these tumour was done with age, clinical presentation, histomorphological patterns, and ER and PR status.

\section{RESULTS}

The present study of Surface Epithelial Ovarian Tumours included a total of 58 cases. Most of the patients with ovarian tumours were in the 2 nd to 5 th decade. Out of 58 cases, majority were Benign tumours (87.93\%), followed by Malignant (8.62\%), and $3.45 \%$ case of Borderline malignancy. Serous tumours were the most common tumours (79.31\%) followed by Mucinous tumours (20.69\%). Amongst Malignant Surface Epithelial tumours, Serous Cystadenocarcinoma was the commonest (60\%). Serous tumours showed higher ER and PR expression (91.67\%) than Mucinous tumours (8.33\%).

\section{CONCLUSION}

Out of 58 surface epithelial tumours of ovary studied in the present study, benign surface epithelial tumours were more common (87.93\%) than malignant tumours (8.62\%). Most common age group for benign SETs was 31-40 years (18 out of 51 making it 35.29\%). Maximum number of malignant tumours were found in the age between 41-50 years and for all aged groups, benign tumours were more common than malignant. Serous tumours showed higher ER and PR expression (91.67\%) than Mucinous tumours (8.33\%).

\section{KEYWORDS}

Surface Epithelial Tumours, Ovarian Tumours, Oestrogen Receptor, Progesterone Receptor.

HOW TO CITE THIS ARTICLE: Harke AB, Madhumittha R, Manjani S, et al. Histopathological patterns of surface epithelial tumours of ovary with oestrogen and progesterone receptor expression. J. Evolution Med Dent Sci. 2016;5(67):4783-4789, D0I: $10.14260 /$ jemds/2016/1090

\section{INTRODUCTION}

Ovarian neoplasms represent the $6^{\text {th }}$ most common malignancy and fourth leading cause of death due to cancers in women and second most common site for female genital tract and are seen usually after $3^{\text {rd }}$ decade of life.

Financial or Other, Competing Interest: None.

Submission 09-02-2016, Peer Review 07-03-2016,

Acceptance 12-03-2016, Published 20-08-2016.

Corresponding Author:

Arun B. Harke,

Professor of Pathology,

Karpaga Vinayaga Institute of Medical Sciences and Research Centre,

G.ST. Road, Chinna Kolambakkam-603308,

Palayanoor Post, Maduranthakam Taluk,

Kanchipuram District,

E-mail: arun_harke@yahoo.com

DOI: $10.14260 /$ jemds $/ 2016 / 1090$
The incidence of ovarian neoplasms varies in different parts of the world. The difference is also noted in the type of ovarian cancer seen in Western countries and Asian continents. Surface epithelial tumours being more common in the former and germ cell tumours in the latter. ${ }^{1-4}$

In 1929, Taylor was first one to describe the subset of epithelial ovarian tumours that he termed as semi-malignant, which had favourable outcome than do other ovarian cancers, but they were not separately classified by FIGO and WHO until the early 1970 s. $^{2}$

They are heterogeneous neoplasms, which are primarily divided depending upon the cell type into Serous, Endometrioid, Mucinous, Transitional, Clear cell, and Squamous cell tumours. Furthermore, depending on the degree of cellular proliferation, atypia of nuclei and the 
presence or absence of stromal invasion, they are subdivided into Benign, Borderline (Intermediate), and Malignant (Carcinoma).5,6

It occurs due to the dedifferentiation of the cells overlying the ovary. At ovulation time, they are incorporated into the ovary and proliferate. Ovarian cancers typically spreads to peritoneum and omentum. They spread by local, lymphatic, intraperitoneal, haematogenous, and transdiaphragmatic route. The most common route is an intraperitoneal one, which occurs along peritoneal fluid collection and at the sites of stasis. The haematogenous route is an unusual one in the initial stage of the disease. ${ }^{2}$

\section{MATERIALS AND METHODS}

A detailed retrospective and prospective study of 70 ovarian neoplasms was done from August 2012 to July 2015 taking into account the relevant clinical data. In the retrospective study, the available $\mathrm{H}$ and $\mathrm{E}$ slides and paraffin blocks of the ovarian tumours in the department were studied from August 2012 to July 2013 and the data was retrieved from the record files of the Pathology Department.

In the prospective study, every excised surgical specimen of ovarian tumour from August 2013 to July 2015 were included. All cystectomy, oophorectomy, and total abdominal hysterectomy with bilateral or unilateral salpingooophorectomy were included in the present study. Exclusion criteria set during the present study was to exclude all those patients having abdominal masses due to causes other than ovarian tumours. Thorough grossing was done and multiple representative sections were taken and the tissue was processed by routine histological techniques and subjected for Haematoxylin and Eosin stain. In certain surface epithelial tumours, ER and PR status was also found out by doing IHC study.

The nature of ovarian tumour was categorised based on WHO Classification, 2003.7 The analysis of data accumulated was done by descriptive statistics.

\section{RESULTS}

A total of 70 cases of ovarian tumours have been reported in the same period, out of which 58 were Surface Epithelial Tumours of Ovary. Amongst 58 Surface Epithelial Tumours of Ovary, 51 were Benign (87.93\%), 2 were Borderline (3.45\%), and 5 were Malignant (8.62\%).

\begin{tabular}{|c|c|c|c|}
\hline $\begin{array}{l}\text { Name of } \\
\text { Tumour }\end{array}$ & No. & $\begin{array}{c}\text { \% Amongst } \\
\text { Total Benign } \\
\text { Surface } \\
\text { Epithelial } \\
\text { Tumours } \\
(\mathrm{N}=\mathbf{5 1}) \\
\end{array}$ & $\begin{array}{l}\text { \% Amongst } \\
\text { Total Ovarian } \\
\text { Neoplasms } \\
(\mathbf{N}=\mathbf{7 0})\end{array}$ \\
\hline Serous type & 40 & 78.43 & 57.14 \\
\hline $\begin{array}{c}\text { Mucinous } \\
\text { cystadenoma }\end{array}$ & 10 & 19.61 & 14.29 \\
\hline $\begin{array}{l}\text { Brenner } \\
\text { tumour }\end{array}$ & 1 & 1.96 & 1.43 \\
\hline Total & 51 & 100 & 72.86 \\
\hline
\end{tabular}

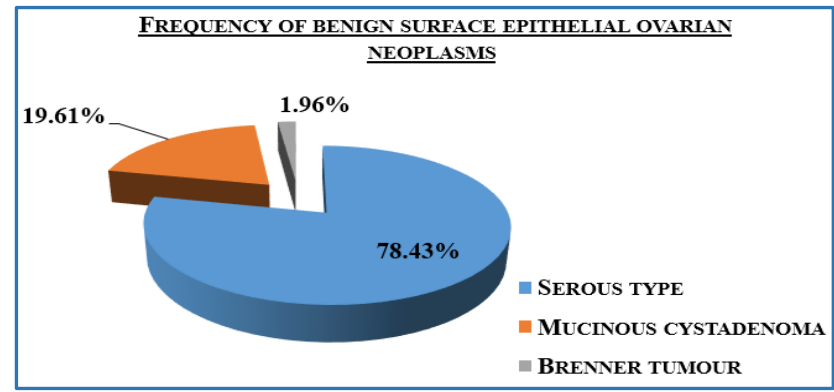

Amongst the benign surface epithelial tumours, serous tumours were highest $(78.43 \%)$ followed by mucinous tumours (19.61\%) and one was benign Brenner (1.96\%). Amongst total ovarian neoplasms, serous benign tumours comprised of $57.14 \%$ followed by $14.29 \%$ of mucinous tumours and benign Brenner being 1.49\%.

\begin{tabular}{|c|c|}
\hline Name of the Tumour & No \\
\hline Borderline Mucinous tumour & 01 \\
\hline Proliferating Brenner tumour8 & 01 \\
\hline Total & 02 \\
\hline $\begin{array}{c}\text { Table 2: Frequency of Borderline Sur } \\
\text { Neoplasms }\end{array}$ & \\
\hline
\end{tabular}

Out of 70 cases of ovarian tumours studied, only 2 Borderline Surface Epithelial Tumours were detected (2.86\%), one Borderline Mucinous (Fig: 1 and 2), and the other being Proliferating Brenner Tumour. ${ }^{8}$

\begin{tabular}{|c|c|c|c|}
\hline Nature of Lesion & No. & $\begin{array}{l}\% \text { Among } \\
\text { Total } \\
\text { Malignant } \\
\text { Set }(n=5)\end{array}$ & $\begin{array}{l}\% \text { Out of } \\
\text { Total } \\
\text { Malignant } \\
\text { Ovarian } \\
\text { Neoplasms } \\
\text { (n=7) }\end{array}$ \\
\hline $\begin{array}{c}\text { Serous } \\
\text { cystadenocarcinoma }\end{array}$ & 03 & 60 & 42.85 \\
\hline Mucinous carcinoma & 01 & 20 & 14.29 \\
\hline $\begin{array}{l}\text { Endometrioid } \\
\text { Carcinoma }\end{array}$ & 01 & 20 & 14.29 \\
\hline Total & 05 & 100 & 71.43 \\
\hline \multicolumn{4}{|c|}{$\begin{array}{c}\text { Table 3: Frequency of Nature of Malignant } \\
\text { Surface Epithelial Neoplasms }\end{array}$} \\
\hline
\end{tabular}

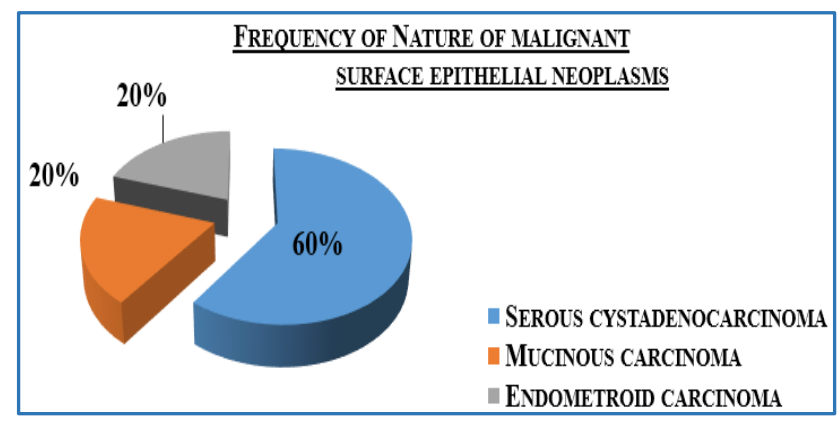

Out of total 5 Malignant Surface Epithelial tumours, the most common was Serous Cystadenocarcinoma 3 in number (60\%), followed by 1 each of Mucinous (20\%), and Endometrioid Carcinoma (20\%) [Fig: 3, 4, and 5].

In the present study, most common SETs were Serous in nature i.e., 43, wherein 40 were Benign (93\%) and 3 were Malignant (7\%); whereas out of 12 Mucinous Tumours, 10 (83.33\%) were Benign and 1 each of Borderline (8.33) and Malignant (8.33\%) respectively. 


\begin{tabular}{|c|c|c|c|c|c|c|c|}
\hline \multirow{2}{*}{ Diagnosis } & \multicolumn{7}{|c|}{ Age Group (Yrs.) } \\
\cline { 2 - 8 } & Up to 20 Yrs. & $\mathbf{2 1 - 3 0}$ Yrs. & $\mathbf{3 1 - 4 0}$ Yrs. & $\mathbf{4 1 - 5 0}$ Yrs. & $\mathbf{5 1 - 6 0}$ Yrs. & $>\mathbf{6 0}$ Yrs. & Total (\%) \\
\hline Serous cystadenoma & $2(3.92 \%)$ & $7(13.7 \%)$ & $14(27.45 \%)$ & $10(19.6 \%)$ & $6(11.77 \%)$ & $1(1.96 \%)$ & $40(78.43 \%)$ \\
\hline Mucinous cystadenoma & $1(1.96 \%)$ & $2(3.92 \%)$ & $3(5.88 \%)$ & $2(3.92 \%)$ & $2(3.92 \%)$ & - & $10(19.6 \%)$ \\
\hline Brenner tumour & - & - & $1(1.96 \%)$ & - & - & - & $01(1.96 \%)$ \\
\hline TOTAL & $\mathbf{3}(\mathbf{5 . 8 8} \%)$ & $\begin{array}{c}\mathbf{9} \\
(\mathbf{1 7 . 0 2} \%)\end{array}$ & $\mathbf{1 8}(\mathbf{3 5 . 2 9 \% )}$ & $\begin{array}{c}\mathbf{1 2} \\
(\mathbf{2 3 . 5 2} \%)\end{array}$ & $\mathbf{8}(\mathbf{1 5 . 6 9 \% )}$ & $\begin{array}{c}\mathbf{1} \\
(\mathbf{1 . 9 6 \% )}\end{array}$ & $\mathbf{5 1}(\mathbf{1 0 0 \% )}$ \\
\hline
\end{tabular}

Most common age group for Benign SETs was 31-40 years (18 out of 51 making it 35.29\%)

\begin{tabular}{|c|c|c|c|c|c|c|c|}
\hline \multirow[b]{2}{*}{ Diagnosis } & \multicolumn{7}{|c|}{ Age Group (Yrs.) } \\
\hline & Up to 20 Yrs. & 21-30 Yrs. & 31-40 Yrs. & 41-50 Yrs. & 51-60 Yrs. & $\begin{array}{l}>60 \\
\text { Yrs. }\end{array}$ & Total (\%) \\
\hline Serous cystadenocarcinoma & - & - & $01(20 \%)$ & $02(40 \%)$ & - & - & $03(60 \%)$ \\
\hline Mucinous carcinoma & - & - & - & $01(20 \%)$ & - & - & $01(20 \%)$ \\
\hline $\begin{array}{c}\text { Endometrioid } \\
\text { adenocarcinoma }\end{array}$ & - & - & - & $01(20 \%)$ & - & - & $01(20 \%)$ \\
\hline TOTAL & - & - & $1(20 \%)$ & $4(80 \%)$ & - & - & $\begin{array}{c}05 \\
(100 \%)\end{array}$ \\
\hline
\end{tabular}

Maximum number of malignant tumours were found in the age between 41-50 years and for all aged groups, benign tumours were more common than malignant.

\section{Unilateral/Bilateral Involvement}

Out of 51 Benign Surface epithelial tumours, 3 were bilateral (5.88\%) and remaining 48 were unilateral (94.12\%). Out of 5 malignant surface epithelial tumours, 2 were bilateral $(40 \%)$ and remaining 3 were unilateral $(60 \%)$. The most common bilateral tumour encountered in the present study were Serous Tumours.

Nature of Tumours

IMMUNOHISTOCHEMISTRY

\begin{tabular}{|c|c|c|c|c|c|c|c|c|c|}
\hline Sl. No. & Age & HPE No & HPE Diagnosis & ER & PR & ER-PR- & ER-PR+ & ER+PR- & ER+PR+ \\
\hline 1 & 50 & $621 / 13$ & Endometrioid adenocarcinoma & - & - & 1 & & & \\
\hline 2 & 50 & $817 / 13$ & Papillary serous adenocarcinoma & + & - & & & 1 & \\
\hline 3 & 46 & $223 / 13$ & Mucinous carcinoma & - & - & 1 & & & \\
\hline 4 & 45 & $615 / 15$ & Invasive high-grade Serous Carcinoma & + & + & & & & 1 \\
\hline 5 & 37 & $030 / 15$ & Borderline Mucinous tumour & - & + & & 1 & & \\
\hline 6 & 40 & $264 / 15$ & Serous Cystadenoma & + & + & & & & 1 \\
\hline 7 & 35 & $1165 / 14$ & Mucinous Cystadenoma & - & - & 1 & & & \\
\hline 8 & 30 & $864 / 14$ & Mucinous Cystadenoma & - & - & 1 & & & \\
\hline 9 & 32 & $501 / 13$ & Serous Cystadenoma & - & - & 1 & & & \\
\hline 10 & 40 & $085 / 15$ & Serous Cystadenoma & + & - & & & 1 & \\
\hline 11 & 48 & $279 / 15$ & Mucinous Cystadenoma & + & + & & & & 1 \\
\hline 12 & 60 & $431 / 15$ & Serous Adenofibroma & - & + & & 1 & & \\
\hline 13 & 50 & $847 / 14$ & Papillary Serous Cystadenoma & - & - & 1 & & & \\
\hline 14 & 33 & $314 / 13$ & Serous Cystadenoma & - & - & 1 & & & \\
\hline 15 & 40 & $594 / 13$ & Serous Cystadenoma & - & - & 1 & & & \\
\hline 16 & 34 & $347 / 13$ & Bilateral Mucinous Cystadenoma & - & - & 1 & & & \\
\hline 17 & 20 & $400 / 13$ & Right Mucinous Cystadenoma & - & - & 1 & & & \\
\hline 18 & 65 & $679 / 13$ & Left Mucinous Cystadenoma & - & - & 1 & & & \\
\hline 19 & 23 & $023 / 13$ & Left Serous Cystadenoma & + & + & & & & 1 \\
\hline 20 & 45 & $121 / 13$ & Right Serous Cystadenoma & + & + & & & & 1 \\
\hline 21 & 45 & $262 / 13$ & Papillary Serous Cystadenoma & + & + & & & & 1 \\
\hline 22 & 50 & $344 / 13$ & Serous Cystadenoma & + & + & & & & 1 \\
\hline 23 & 39 & $360 / 13$ & Serous Cystadenoma & + & + & & & & 1 \\
\hline 24 & 35 & $372 / 13$ & Serous Cystadenoma & + & + & & & & 1 \\
\hline
\end{tabular}

Out of 51 Benign Surface epithelial tumours, 50 were cystic in nature $(90 \%)$ and 1 was solid and cystic in nature (10\%). Out of 5 Malignant Surface Epithelial tumours, 3 were solid and cystic (60\%), 1 was solid (20\%), and 1 was cystic in nature (20\%).

\section{Mode of Presentation}

In the present study, the patients presented with a combination of clinical symptoms consisting of abdominal discomfort, pain in abdomen, mass per abdomen, and menstrual irregularities. One case of Serous Cystadenoma presented with primary infertility. 


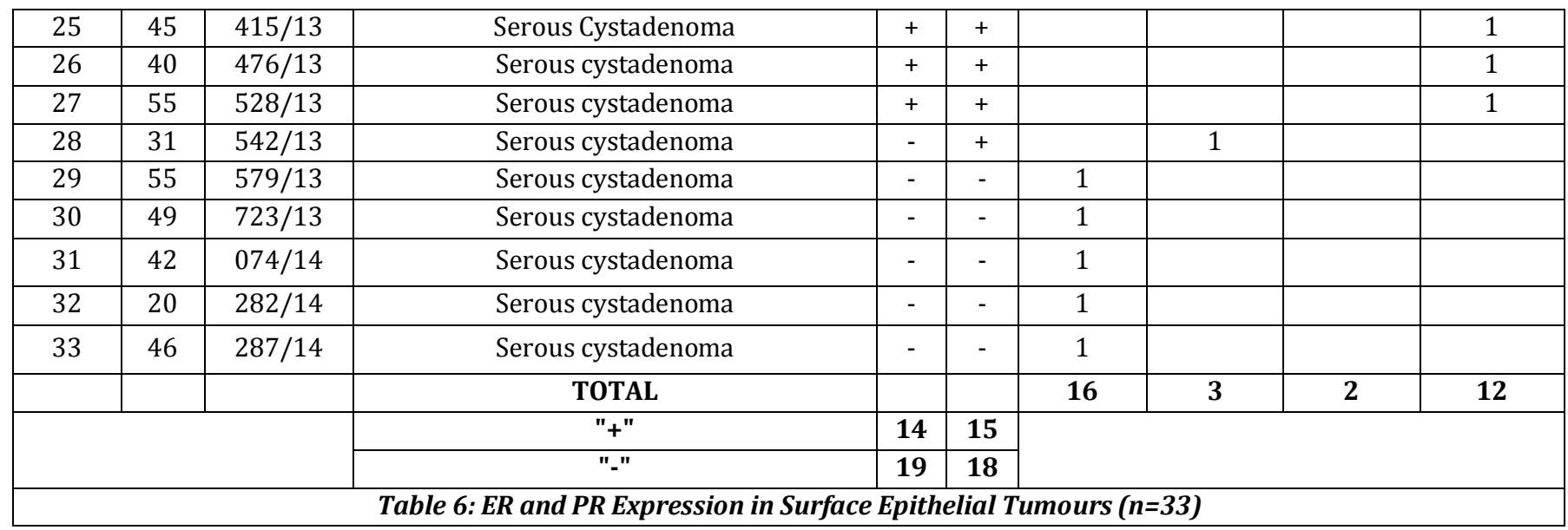

IHC in present study showed ER positivity in 14 and PR positivity in 15 Surface Epithelial Tumours.

ER positivity $(n=14)$ was seen in 13 Serous tumours and one Mucinous tumour. Out of 13 Serous tumours, 11 were Benign Serous tumours and 2 Serous Cystadenocarcinoma and the sole Mucinous tumour was Mucinous Cystadenoma.

PR positivity ( $\mathrm{n}=15)$ was seen in 13 Serous tumours and 2 Mucinous tumours. Of the 13 Serous tumours, 12 were Benign Serous tumours and one Serous Cystadenocarcinoma. Two Mucinous tumours included one Mucinous Cystadenoma and one Borderline Mucinous tumour.

Sixteen Surface Epithelial tumours were both ER and PR-ve, which included 9 Serous Cystadenomas, 5 Mucinous Cystadenomas, one Mucinous Carcinoma, and one Endometrioid Carcinoma.

ER-ve and PR positivity was seen in 3 cases, i.e., 2 Serous Cystadenoma and one Borderline Mucinous tumour.

ER+ve and PR negativity was seen in 2 cases, which included one Serous Carcinoma and one Serous Cystadenoma.

\begin{tabular}{|c|c|c|c|}
\hline AGE & <40 Yrs. & $\mathbf{4 0 - 5 0}$ Yrs. & $>$ 50 Yrs. \\
\hline $\begin{array}{c}\text { ER positive } \\
\text { n=14 }\end{array}$ & $3(21.43 \%)$ & $10(71.43 \%)$ & $1(7.14 \%)$ \\
\hline $\begin{array}{c}\text { PR positive } \\
\text { n=15 }\end{array}$ & $5(33.33 \%)$ & $8(53.33 \%)$ & $2(13.33 \%)$ \\
\hline \multicolumn{4}{|c|}{ Table 7: Correlation of Receptors with Age } \\
\hline
\end{tabular}

ER and PR expression was predominantly seen in 40-50 yrs.

\begin{tabular}{|c|c|c|c|c|}
\hline 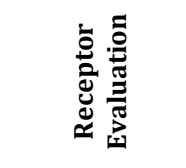 & 氙高 & 氖苛 & 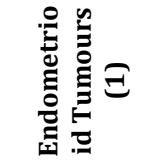 & $\frac{0}{2}$ \\
\hline $\begin{array}{l}\text { ER-ve, PR-ve } \\
(\mathrm{n}=16)\end{array}$ & $\begin{array}{c}9 \\
(37.50 \%)\end{array}$ & $6(75.00 \%)$ & $1(100 \%)$ & - \\
\hline $\begin{array}{l}\text { ER-ve, PR+ve } \\
(n=3)\end{array}$ & $2(8.33 \%)$ & $1(12.50 \%)$ & - & - \\
\hline $\begin{array}{l}\text { ER +ve, PR-ve } \\
(n=2)\end{array}$ & $2(8.33 \%)$ & - & - & - \\
\hline $\begin{array}{l}\text { ER+ve, PR+ve } \\
(n=12)\end{array}$ & $\begin{array}{c}11 \\
(45.83 \%) \\
\end{array}$ & $1(12.50 \%)$ & - & $\begin{array}{c}0.000 \\
1\end{array}$ \\
\hline \multicolumn{5}{|c|}{$\begin{array}{c}\text { Table 8: Expression of Oestrogen and Progesterone } \\
\text { Receptors in SETS }\end{array}$} \\
\hline
\end{tabular}

$\mathrm{P}$ value was calculated using chi-square test by considering the actual and expected/average range. ER and PR expression was higher in Serous tumours (45.83\%) than Mucinous tumours (12.50\%) [Fig: 6 and 7].

\begin{tabular}{|c|c|c|c|}
\hline $\begin{array}{l}\text { Type of Surface } \\
\text { Epithelial } \\
\text { Tumours }\end{array}$ & $\begin{array}{l}\text { Nature of } \\
\text { Tumour }\end{array}$ & $\begin{array}{c}\text { No. of } \\
\text { Cases } \\
\text { where } \\
\text { IHC was } \\
\text { done }\end{array}$ & $\begin{array}{c}\text { No. of ER } \\
\text { and PR } \\
\text { Positive }\end{array}$ \\
\hline \multirow{3}{*}{ Serous (24) } & Benign & 22 & 10 \\
\hline & Borderline & - & - \\
\hline & Malignant & 02 & 01 \\
\hline \multirow{3}{*}{ Mucinous (8) } & Benign & 06 & 01 \\
\hline & Borderline & 01 & - \\
\hline & Malignant & 01 & - \\
\hline \multirow{3}{*}{$\begin{array}{c}\text { Endometrioid } \\
\text { (1) }\end{array}$} & Benign & - & - \\
\hline & Borderline & - & - \\
\hline & Malignant & 01 & - \\
\hline
\end{tabular}

Benign Serous tumours showed ER and PR positivity in $45.45 \%$ cases $(10 / 22)$.

Out of two Malignant Serous tumours, one showed ER and PR positivity (50\%).

Among 6 Benign Mucinous tumours, only one showed both ER and PR positivity (16.66\%). The sole Malignant Mucinous tumour observed in the present study turned out to be ER and PR negative.

Similarly, the sole Endometrioid Adenocarcinoma encountered in the present study was negative for ER and PR.

\section{DISCUSSION}

Amongst the Surface Epithelial Tumours, Serous subtypes were more common than Mucinous subtypes despite of its Benign, Borderline, or Malignant nature.

\begin{tabular}{|c|c|c|c|}
\hline \multirow{2}{*}{ Studies } & Name of Tumour & $\begin{array}{c}\% \\
\text { Amongst } \\
\text { Total } \\
\text { Benign } \\
\text { Tumours }\end{array}$ & $\begin{array}{c}\text { \% } \\
\text { Amongst } \\
\text { Total } \\
\text { Ovarian } \\
\text { Tumours }\end{array}$ \\
\hline \multirow{2}{*}{$\begin{array}{c}\text { Vaddatti } \\
\text { et al9 }\end{array}$} & Serous tumour & $64.48 \%$ & $50.72 \%$ \\
\cline { 2 - 4 } & Mucinous & $21.66 \%$ & $16.90 \%$ \\
\cline { 2 - 4 } cystadenomas & Brenner type & $0.92 \%$ & $0.72 \%$ \\
\hline \multirow{2}{*}{$\begin{array}{c}\text { Present } \\
\text { study }\end{array}$} & Serous tumour & $65.57 \%$ & $57.14 \%$ \\
\cline { 2 - 4 } & Mucinous tumour & $16.39 \%$ & $14.29 \%$ \\
\cline { 2 - 4 } & Brenner tumour & $1.64 \%$ & $1.43 \%$ \\
\hline \multicolumn{4}{|c|}{ Table 10: Comparative Analysis of Benign SETs } \\
\hline
\end{tabular}




\begin{tabular}{|c|c|c|c|}
\hline Studies & Name of Tumour & $\begin{array}{c}\% \text { Among } \\
\text { Total } \\
\text { Malignant } \\
\text { Tumours }\end{array}$ & $\begin{array}{c}\% \\
\text { Among } \\
\text { Total } \\
\text { Ovarian } \\
\text { Tumours }\end{array}$ \\
\hline \multirow{5}{*}{$\begin{array}{l}\text { Vaddatti } \\
\text { et } \text { al }^{9}\end{array}$} & Serous tumour & $49.18 \%$ & $10.79 \%$ \\
\hline & Mucinous type & $21.30 \%$ & $4.48 \%$ \\
\hline & Endometrioid type & $3.28 \%$ & $0.73 \%$ \\
\hline & Clear cell type & $1.64 \%$ & $0.36 \%$ \\
\hline & Brenner type & $1.64 \%$ & $0.36 \%$ \\
\hline \multirow{3}{*}{$\begin{array}{l}\text { Present } \\
\text { Study }\end{array}$} & $\begin{array}{c}\text { Serous } \\
\text { cystadenocarcino } \\
\text { ma }\end{array}$ & $42.86 \%$ & $4.29 \%$ \\
\hline & $\begin{array}{c}\text { Mucinous } \\
\text { carcinoma }\end{array}$ & $14.29 \%$ & $1.43 \%$ \\
\hline & $\begin{array}{l}\text { Endometrioid } \\
\text { adenocarcinoma }\end{array}$ & $14.29 \%$ & $1.43 \%$ \\
\hline
\end{tabular}

In R Jha et al10 study, $78.9 \%$ of serous tumours were benign and $21.1 \%$ were malignant; similarly $77.8 \%$ of mucinous tumours were benign neoplasms while $22.2 \%$ were malignancies analogous to present study; amongst serous $93 \%$ were benign and $7 \%$ were malignant. In Nital et $\mathrm{al}^{11}$ study alike of present study among mucinous tumours 12 were benign (80\%), 1 borderline (6.7\%), and 2 malignant $(13.3 \%)$. In present study, out of 12 mucinous tumours, 10 $(83.3 \%)$ were benign (83.3\%), 1 borderline (8.3\%), and 1 was malignant $(8.3 \%)$.

The present study highlights the occurrence of serous tumours (in spite of being benign/malignant) as the most common as compared to mucinous tumours. This observation correlates with many other studies like Nital et al,11 Vaddatti et al, ${ }^{9}$ Summyia Farooq et al, ${ }^{4}$ Ameena Ashraf et al,12 and GG Swamy et al. ${ }^{13}$

Benign Brenner tumour observed in the present study was an incidental finding coinciding with the findings in literature. ${ }^{14}$ It enacts $1.43 \%$ of all ovarian tumours. Proliferating Brenner 8 was also accounted for the same percentage as above.

Among overall benign lesions, serous tumours were also the commonest ones.

There were 3 Serous Cystadenocarcinoma, one Endometrioid Adenocarcinoma, and one Mucinous Carcinoma [Fig: 3, 4, and 5]. Serous Cystadenocarcinoma had an incidence of $4.29 \%$ of overall ovarian tumours. Endometrioid accounted for $1.43 \%$ of entire ovarian neoplasms. Serous over rides other subtypes of SETs.

\section{Age}

All the Surface Epithelial Tumours were observed between the age group 10-80 years finding similar to Nital et al,11 Kanthikar S N et al,15 A Pradhan et al,16 Vaddatti et al, ${ }^{9}$
Ameena Asraf et al, 12 and $\mathrm{R}$ Jha et al. ${ }^{10}$ The youngest patient was 10 years old and oldest was 75 yrs., both of them presented with serous cystadenoma. 31-40 yrs. of age group showed maximum number of cases. However, the rate of incidence peaks as the age advances.

31-40 yrs. age group was the one where Benign Ovarian Surface Epithelial tumours mainly fell, which is parallel to Vaddatti et $\mathrm{al}^{9}$ and $\mathrm{R}$ Jha et al.10

Malignant Surface Epithelial tumours specifically glimpsed among 41-50 yrs. congruent to Vaddatti et $\mathrm{al}^{9}$ and $\mathrm{R}$ Jha et al. ${ }^{10}$

\section{Site of Involvement:}

Out of 51 Benign Surface epithelial tumours, 3 were bilateral (5.88\%) and remaining 48 were unilateral (94.12). Out of 5 Malignant Surface Epithelial tumours, 2 were bilateral (40\%) and remaining 3 were unilateral $(60 \%)$. The most common bilateral tumour encountered in the present study were Serous Tumours.

Thus, unilateral involvement was more common than bilateral one coinciding with other findings of Nital et al,11 Kanthikar S. N. et al, ${ }^{15}$ and A Pradhan et al. ${ }^{16}$

\section{Mode of Presentation:}

In the present study, the patients presented with a combination of clinical symptoms consisting of abdominal discomfort, pain in abdomen, mass per abdomen, and menstrual irregularities. One case of Serous Cystadenoma presented with primary infertility. Most of the patients presented with mass per abdomen similar to observations noted by Nital et al,11 Kanthikar et al,15 and A Pradhan et $\mathrm{al}^{16}$ in their studies.

\section{Nature of Tumours}

The greater numbers of benign lesions were cystic and malignancies were solid and mixed, this goes in agreement with findings of Nital et al,11 Kanthikar $\mathrm{S} N$ et al,15 and $\mathrm{A}$ Pradhan et al. ${ }^{16}$

\section{ER and PR Expression}

Both, the hormones with its receptors are involved in the process of tumour genesis of ovaries. It is involved by the disruption of the cell cycle, apoptosis, and DNA repair.17,18

In present study, ER and PR were positive more in serous tumours compared to other SETs like mucinous tumours and Endometrioid Adenocarcinoma, corresponding with the results of Summyia Farooq et al, ${ }^{4}$ Hugo Arias-Pulido et al, ${ }^{19}$ and Sylvia et al. ${ }^{20}$

\begin{tabular}{|c|c|c|c|c|c|c|}
\hline ER and PR Expression & \multicolumn{2}{|c|}{ Hugo Arias-Pulido et al19 } & Summyia Farooq et al ${ }^{4}$ & \multicolumn{2}{c|}{ Present Study } \\
\hline & Serous & Mucinous & Serous & Mucinous & Serous & Mucinous \\
\hline ER-PR- & $12(18.5 \%)$ & $15(62.5 \%)$ & $17(48.57 \%)$ & $13(86.6 \%)$ & $09(37.50 \%)$ & $06(75.00 \%)$ \\
\hline ER-PR+ & $09(13.9 \%)$ & $04(16.7 \%)$ & $5(14.28 \%)$ & $1(6.67 \%)$ & $02(8.33 \%)$ & $01(12.50 \%)$ \\
\hline ER+PR- & $15(23.1 \%)$ & $03(12.5 \%)$ & 0 & 0 & $2(8.33 \%)$ & - \\
\hline ER+PR+ & $29(44.6 \%)$ & $02(8.35)$ & $13(37.14 \%)$ & $1(6.67 \%)$ & $11(45.83 \%)$ & $01(12.50 \%)$ \\
\hline \multicolumn{7}{|c|}{ Table 12: Comparative Study of Er and Pr Expression in Surface Epithelial Tumours } \\
\hline
\end{tabular}

In Summyia Farooq.et $a^{4}$ study, the more number of ER and PR positive cases were seen in $>50$ years of age group accounting for $75 \%$; Sylvia et $a l, 20$ study also quoted similar finding. However, in the present study, more number of ER and PR positive cases was seen in 41-50 yrs. of age group. 
Amongst serous tumours, Summyia Farooq et $\mathrm{al}^{4}$ found oestrogen receptor expression in 8 Malignant tumours, one borderline and 4 Benign tumours and progesterone receptor expression in 11 Malignant, one Borderline, and 6 Benign serous tumour. In Mucinous tumours, they found ER expression in only 1 malignant tumour and PR expression in 1 Borderline and 1 Malignant tumour.

In the present study, among serous tumours, oestrogen receptors were expressed in 2 Malignant and 11 Benign tumours, and progesterone receptors were expressed in 1 Malignant and 11 Benign tumour.
In Mucinous tumours, ER was expressed in 1 benign tumour and PR in 1 benign and 1 borderline tumour.

Thus to conclude, ER and PR expression is higher in serous tumours than in mucinous tumours [Fig 6 and 7].

The numbers of Borderline and Malignant tumours in the present study were less as compared to other studies and hence we cannot hypothesise regarding the different level of ER and PR expression in benign versus borderline and malignant tumours.
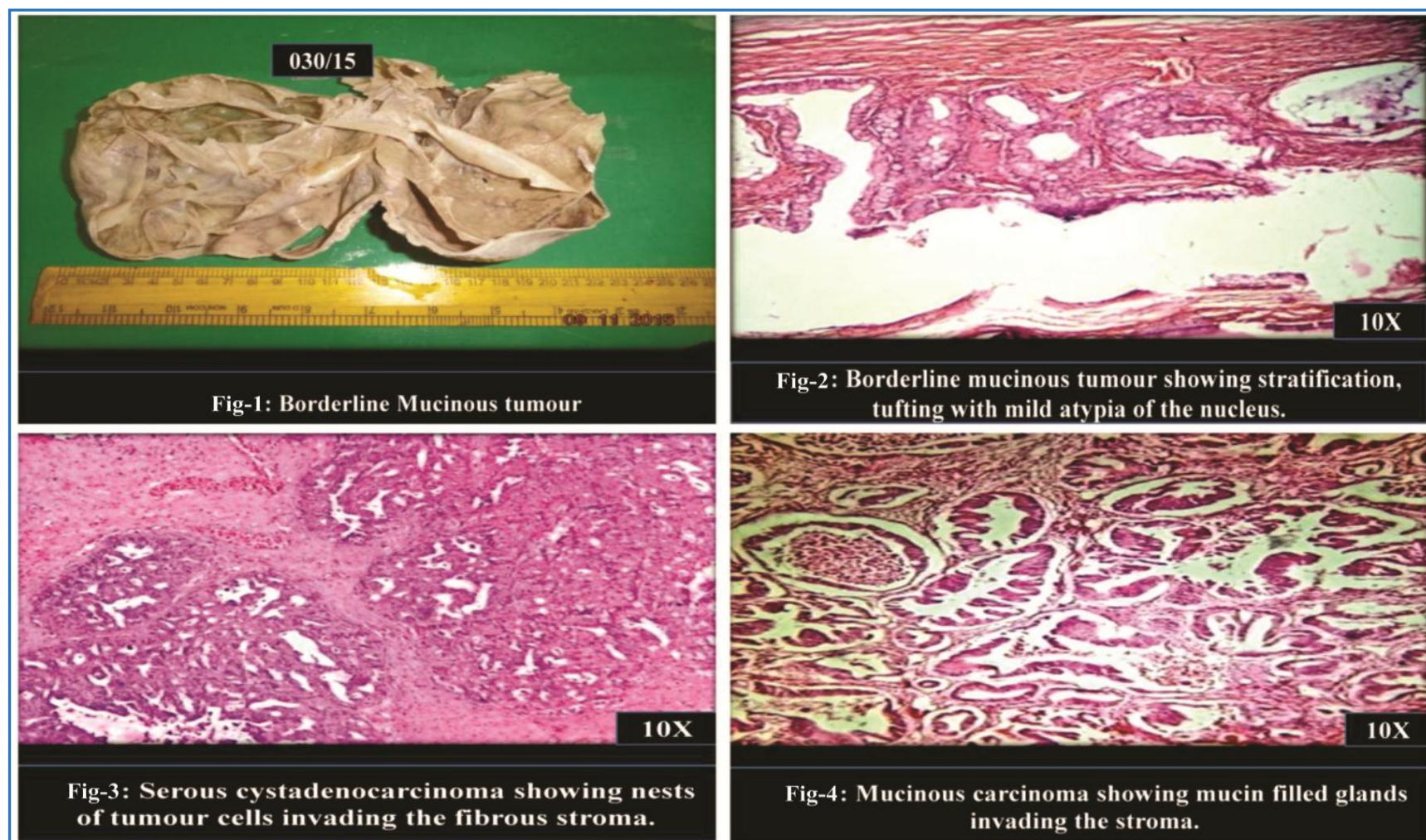

Fig-2: Borderline mucinous tumour showing stratification, tufting with mild atypia of the nucleus.

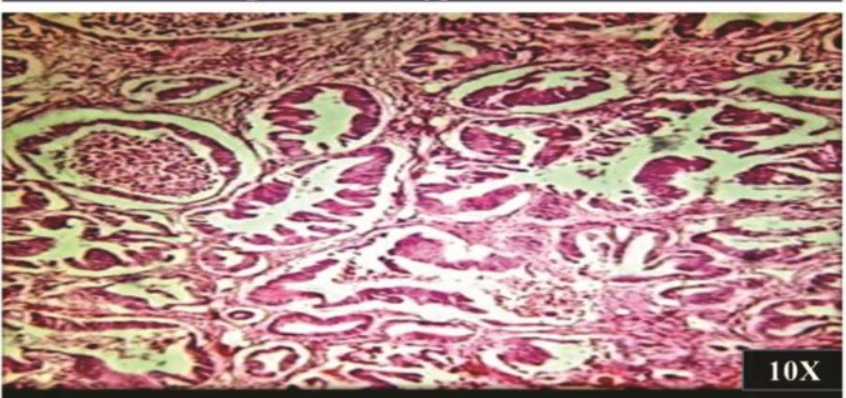

Fig-4: Mucinous carcinoma showing mucin filled glands invading the stroma.
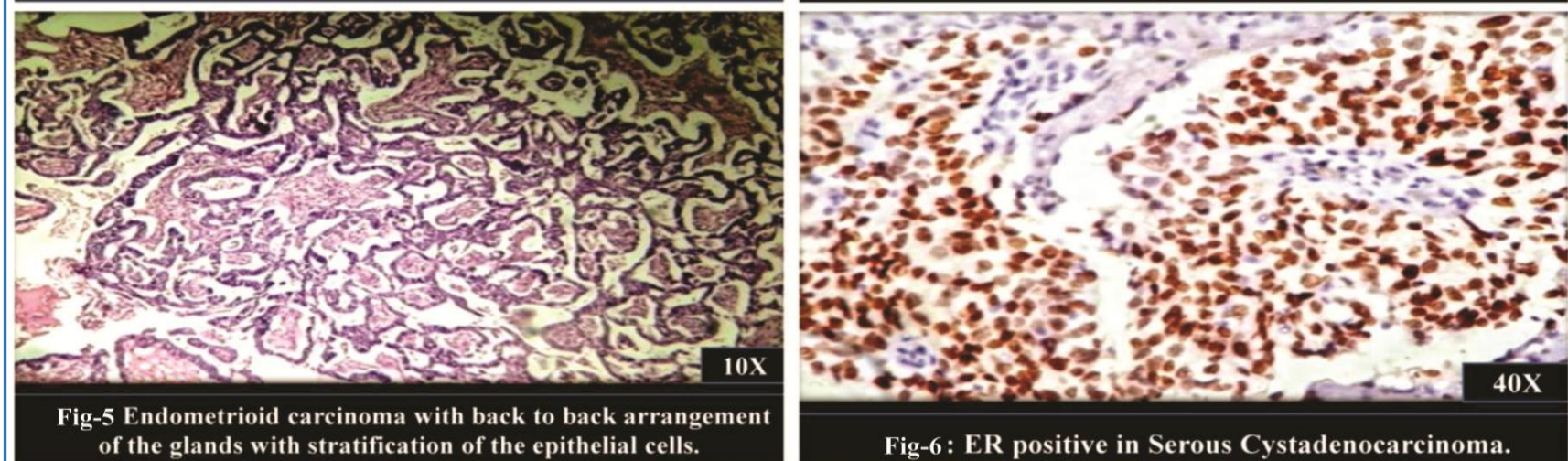

Fig-6 : ER positive in Serous Cystadenocarcinoma.

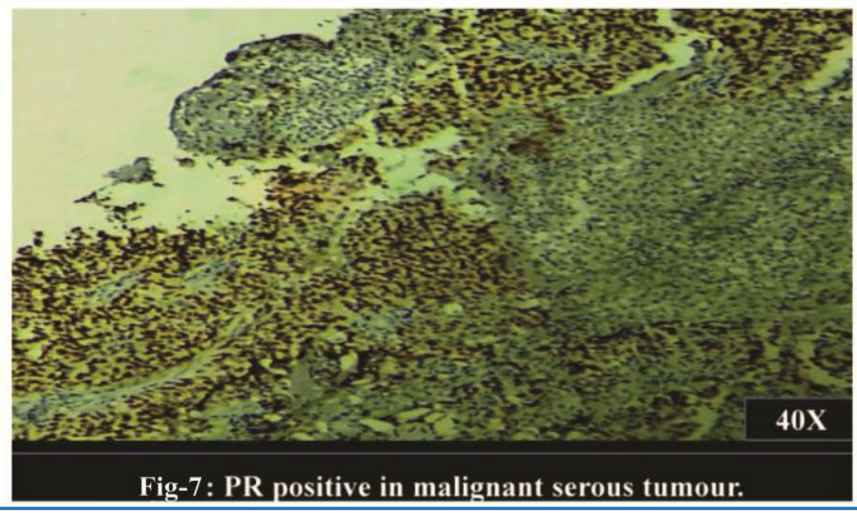




\section{CONCLUSION}

A retrospective and prospective analysis of 70 consecutive ovarian tumours was done in Department of Pathology, Karpaga Vinayaga Institute of Medical Sciences from August 2012 to July 2015. A comprehensive analysis of the data obtained suggested the following:

1. Out of 58 Surface Epithelial tumours of ovary studied in the present study, Benign Surface Epithelial tumours $(87.93 \%)$ were more common than Malignant tumours (8.62\%).

2. Most common age group for Benign SETs was 31-40 years (18 out of 51 making it 35.29\%). Maximum number of Malignant cases were found in the age between 41-50 years and for all aged groups, Benign tumours were more common than Malignant.

3. The most common bilateral tumour encountered in the present study were Serous Tumours.

4. Most of the patients presented with mass per abdomen.

5. Serous tumours (91.67\%) showed higher ER and PR expression than mucinous tumours (8.33\%).

\section{REFERENCES}

1. Dawar R. Surface epithelial tumours of ovary. Indian Journal of Medical and Paediatric Oncology 2004;25(1):5-9.

2. Green AE, Huh WK. Borderline ovarian cancer, borderline tumour overview. Medscape reference Drugs, Disease and procedure 2015.

3. Tortolero LG, Mitchell MF, Rhodes HE. Epidemiology and screening of ovarian cancer. Obstet Gynaecol Clin North Am 1994;21:63-75.

4. Farooq S, Tasleem R, Nazir N, et al. Histopathological patterns of ovarian neoplasms and oestrogen and progesterone receptor expression in primary epithelial tumours and their histopathological correlation. Int J Cur Res Rev 2013;5(21):70.

5. Prat J. Pathology of the ovary. Philadelphia: Saunders 2004.

6. Lee KR, Tavassoli FA, Prat J, et al. Surface epithelialstromal tumours $\mathrm{Ch} \mathrm{2,} \mathrm{tumours} \mathrm{of} \mathrm{the} \mathrm{ovary} \mathrm{and}$ peritoneum. In Tavassoli FA, Devilee P, eds. World Health Organisation Classification of Tumours: pathology and genetics of tumours of the breast and female genital organs. Lyon: IARC Press 2003;117-45.

7. Tavassoli FA, Devilee P. Pathology and genetics of tumours of breast and female genital organs. World Health Organisation of Classification of Tumours 2003.
8. Vimal M, Chitra T, Harke AB. Proliferating Brenner tumour of ovary-a rare entity. IJCRR 2015;7(9):99-101.

9. Tejesweni V, Reddy S, Premalatha P, et al. Study of morphological patterns of ovarian neoplasms. Journal of Dental and Medical Science 2013;10(6):11-6.

10. Jha R, Karki S. Histological pattern of ovarian tumours and their age distribution. Nepal Med Coll J 2008;10(2):81-5.

11. Panchal N, Parikh U. Histopathological patterns of ovarian tumours. International Journal of Scientific Research 2015;4(1).

12. Ashraf A, Shaikh SA, Ishfaq A, et al. The relative frequency and histopathological pattern of ovarian masses. Biomedica 2012;28:98-102.

13. Swamy GG, Satyanarayana N. Clinicopathological analysis of ovarian tumours-a study on five years samples. Nepal Med Coll J 2010;12(4):221-3.

14. Kurman RJ, TeLinde RW. Blaustein's pathology of the female genital tract. $6^{\text {th }}$ ed. Books and eBooks in Mathematics and Statistics. Springer 2011.

15. Kanthikar SN, Dravid NV, Deore PN, et al. Clinicohistopathological analysis of neoplastic and nonneoplastic lesions of the ovary: a 3-year prospective study in Dhule, North Maharashtra, India. J Clin Diagn Res 2014;8(8):FC04-7.

16. Pradhan A, Sinha AK, Upreti D. Histopathological patterns of ovarian tumours at BPKIHS. Department of Pathology and 2 Department of Obstetrics and Gynaecology, BPKIHS, Dharan, Nepal 2012;10(2):87-97.

17. Pertschuk LP, Beddee AM, Gorelic LS, et al. Immune cytochemical assay of oestrogen receptor in endometrioid carcinoma with monoclonal antibodies. Cancer 1986;57:1000-4.

18. Syed V, Ulinski G, Mok SC, et al. Expression of gonadotropin receptor and growth responses to key reproductive hormones in normal and malignant human ovarian surface epithelial cells. Cancer Res 2001;61:6168776.

19. Arias-Pulido H, Smith HO, Joste NE, et al. Oestrogen and progesterone receptor status and outcome in epithelial ovarian cancers and low malignant potential tumours. Gynaecol Oncol 2009;114(3):480-5.

20. Sylvia MT, Kumar S, Dasari P. The expression of immunohistochemical markers oestrogen receptor, progesterone receptor, Her-2-neu, p53, and Ki-67 in epithelial ovarian tumours and its correlation with clinicopathologic variables. Indian journal of pathology and microbiology 2012;55(1):33-7. 